\title{
PERBANDINGAN KEMAMPUAN PEMAHAMAN KONSEP MATEMATIS SISWA DENGAN MODEL PEMBELAJARAN INQUIRY LEARNING DAN MODEL PEMBELAJARAN PROBLEM BASED LEARNING PADA SISWA KELAS VII SMPN 5 KOTA JAMBI
}

\author{
Windi Purnama Sari ${ }^{1}$, Harman $^{2}$, Aisyah $^{3}$ \\ Program Studi Pendidikan Matematika, FKIP, Universitas Batanghari ${ }^{1,2,3}$ \\ Jl. Slamet Riyadi No.1 Broni Jambi \\ e-mail: WindiPs412@gmail.com
}

\begin{abstract}
ABSTRAK
Penelitian ini dilatarbelakangi oleh rendahnya kemampuan pemahaman konsep matematis siswa dalam menyatakan ulang konsep pada siswa kelas VII SMPN 5 Kota Jambi. Hal ini dikarenakan siswa terbiasa menghafal konsep, bukan memahami konsep tersebut. Penelitian ini bertujuan untuk mengetahui perbedaan kemampuan pemahaman konsep matematis siswa yang dibelajarkan dengan menggunakan model pembelajaran Inquiry Learning dan Problem Based Learning. Desain penelitian ini menggunakan penelitian Quasy Eksperimen dengan desain The Randomized Posttest Only Control yang dilakukan terhadap 2 kelas sampel yang diberikan perlakuan berbeda. Pengambilan sampel menggunakan teknik Random Sampling, sampel yang digunakan sebanyak 2 kelas yaitu kelas VII F sebagai kelas eksperimen dan kelas VII I sebagai kelas kontrol. Data penelitian diperoleh dengan memberikan soal posttest kepada kedua kelas sampel. Setelah hasil postes diperoleh, data dianalisis untuk menguji hipotesis dengan menggunakan uji-t. Adapun ratarata dan simpangan baku yang diperoleh kelas eksperimen 82.51 dan 6.97 dan kelas control adalah 78.61 dan 8.32. Dari analisis yang telah dilakukan terhadap hasil postes dapat disimpulkan bahwa kemampuan pemahaman konsep matematis siswa yang menggunakan model pembelajaran Inquiry Learning lebih baik dibandingkan dengan kemampuan pemahaman konsep matematis siswa yang meggunakan model pembelajaran Problem Based Learning.
\end{abstract}

\section{Kata kunci :}

Kemampuan Pemahaman Konsep Matematis Siswa, Model Pembelajaran Inquiry Learning, Model Pembelajaran Problem Based learning.

\begin{abstract}
This research is motivated by the low ability of understanding students' mathematical concepts in restating the concepts in grade VII students of SMPN 5 Jambi City. This is because students are accustomed to memorizing concepts, not understanding them. This study aims to determine differences in students' mathematical concept understanding abilities that are learned using Inquiry Learning and Problem Based Learning models. The design of this study used the Quasy Experiment study with the design of The Randomized Posttest Only Control which was conducted on 2 classes of samples that were given different treatments. Sampling using the Random Sampling technique, the sample used as many as 2 classes, class VII $F$ as an experimental class and class VII I as a control class. The research data were obtained by giving posttest questions to the two sample classes. After the posttest results are obtained, the data are analyzed to test the hypothesis using t-test. The average and standard deviation obtained by the experimental class 82.51 and 6.97 and the control class are 78.61 and 8.32. From the analysis conducted on the results of the posttest it can be concluded that the ability to understand mathematical concepts of students who use Inquiry Learning models is better than the ability to understand mathematical concepts of students who use Problem Based Learning learning models.
\end{abstract}

Keywords :

Ability to Understand Students' Mathematical Concepts, Inquiry Learning Model, Problem Based Learning Model. 


\section{$\pi$ (Phi)}

\section{PENDAHULUAN}

Matematika adalah salah satu cabang ilmu pengetahuan yang memegang Hampir seluruh ilmu pengetahuan dan teknologi menggunakan peranan penting dalam kehidupan manusia. matematika (Fitriani, 2015). Oleh karena itu tidak dapat disangkal bahwa matematika mendasari ilmu pengetahuan dan teknologi. Menurut Permendiknas No 22 Tahun 2006 Tujuan pembelajaran matematika adalah membekali siswa untuk memahami konsep matematika, menggunakan penalaran yang baik, mampu mengkomunikasikan gagasan dengan symbol matematika, mampu memecahkan masalah matematika serta mempunyai sikap menghargai kegunaan matematika. Namun, banyak fakta yang menunjukkan pada saat mata pelajaran matematika berlangsung sebagian siswa kurang aktif dalam proses pembelajaran dikarenakan siswa lebih bersifat pasif atau malu untuk mengemukakan pendapatnya. Sehingga keadaan ini sedikit banyak akan menggangu kelancaran dalam pembelajaran.

Berdasarkan observasi yang dilakukan diketahui bahwa salah satu kebiasaan siswa dalam pembelajaran matematika adalah kebiasaan menghafal konsep tanpa mengerti maksudnya. Salah satu indicator yang jarang tercapai untuk pemahaman konsep matematis yaitu menyatakan ulang konsep dapat dilihat dari soal-soal yang diselesaikan oleh siswa. Kesalahan-kesalahan yang dilakukan oleh siswa tersebut disebabkan karena siswa tidak memahami konsep tersebut. Belajar matematika membutuhkan pemahaman dan bukan hafalan, karna inti dari belajar matematika adalah pemahaman.

Persoalan yang harus diselesaikan adalah bagaimana menemukan cara yang terbaik untuk menyampaikan berbagai konsep yang diajarkan sehingga siswa dapat menggunakan dan mengingat lebih lama konsep tersebut. Penekanan utama dalam pembelajaran matematika yang baik adalah bagaimana siswa mengerti konsep-konsep matematika dengan lebih baik. Pemilihan model pembelajaran diharapkan pembelajaran yang terjadi dapat lebih bermakna. Keadaan ini mendorong peneliti untuk membandingkan dua buah model pembelajaran untuk mengetahui mana yang lebih baik dalam kemampuan pemahaman konsep matematis siswa. Salah satunya adalah model pembelajaran Inquiry Learning.

Model pembelajaran Inquiry Learning adalah salah satu model untuk mengembangkan cara belajar siswa dengan menemukan sendiri, menyelidiki sendiri, sehingga dapat meningkatkan kemampuan pemahaman konsep matematis siswa dengan cara siswa berlatih untuk memiliki pengalaman belajar dan menemukan konsepkonsep materi berdasarkan kejadiankejadian, atau fenomena-fenomena yang diajukan.

Model pembelajaran Inquiry Learning bertujuan untuk mengorganisasikan pengetahuan yang dimiliki siswa, membantu siswa dalam mengembangkan disiplin intelektual siswa yang perlu untuk mencari data, mengolah data, menggunakan logika berpikir terhadap data tersebut Suchman (Hosnan, 2014:345). Judul penelitian ini adalah perbandingan kemampuan pemahaman konsep matematis siswa dengan model pembelajaran Inquiry Learning dan model pembelajaran Problem Based Learning Pada Siswa Kelas VII SMpn 5 Kota Jambi.

\section{METODE PENELITIAN}

Sesuai dengan permasalahan yang telah dikemukakan sebelumnya, maka jenis penelitian ini adalah penelitian Quasi Eksperimen. Menurut Zarkasyi (2015:20) dikatakan penelitian Quasi Eksperimen karena dalam desain ini peneliti dapat mengontrol semua variabel control yang mempengaruhi jalannya eksperimen

Penelitian ini dilakukan terhadap dua kelas, yaitu kelas eksperimen dan kelas control. Pada kelas eksperimen dilakukan dengan model pembelajaran Inquiry Learning dan pada kelas control 


\section{$\pi$ (Phi)}

menggunakan model pembelajaran Problem Based Learning.

Dalam penelitian ini yang akan dijadikan populasi adalah seluruh siswa kelas VIII SMP Negeri 5 Kota Jambi yang terdiri dari sepuluh kelas. Sampel yang digunakan sebanyak dua kelompok sampel yaitu kelompok eksperimen dan kelompok kontrol. Kelompok eksperimen merupakan kelas yang diajarakan dengan model Inquiry Learning dan kelas kontrol merupakan kelas yang diajarkan dengan model pembelajaran Problem Based Learning. pengambilan sampel tersebut menggunakan teknik random sampling, yaitu pengambilan smple secara acak dari populasi yang berdistribusi normal tanpa memperhatikan strata yang ada dalam populasi itu (Sugiyono,2015:82).

Desain penelitian yang digunakan dalam penelitian ini adalah posttest-only control design (Zarkasyi, 2017:127).

\section{HASIL DAN PEMBAHASAN}

Berdasarkan hasil tes akhir (posttest), dilakukan perhitungan karekteristik nilai kemampuan pemahaman konsep matematis siswa dengan menggunakan Software SPSS IBM Versi 20 yang dapat dilihat dalam tabel berikut:

Hasil penelitian berupa uji normalitas, uji homogenitas dan uji hipotesis. Menguji normalitas dan homogenitas data hasil posttest kemampuan pemahaman konsep matematis siswa dikelas eksperimen dan kelas control.

Berdasarkan pengolahan data, maka diperoleh nilai sig. hasil eksperimen sebesar 0.07 yang berarti nilai sig. lebih dari $\alpha(0.07$ $>0.05)$. sedangkan sig.hasil kontrol sebesar 0.09 yang berarti nilai sig. lebih dari (0.09> 0.05). jadi dapat disimpulkan bahwa data berdistribusi normal.

Menguji homogenitas data asli posttest kemampuan pemahaman konsep matematis siswa kelas eksperimen dan kelas control. Berdasarkan hasil output software SPSS diatas, maka didapatkan nilai signifikasi.
Sebesar 0.339 yang bearti nilai hasil postest kelas eksperimen dan kelas kontrol lebih besar dari $\alpha(0.339>0.05)$. jadi dapat disimpulkan bahwa kelas eksperimen dan kelas kontrol memiliki variansi yang sama (homogen).

Pengujian hipotesis ini menggunakan uji t, karena data berdistribusi normal dan memiliki varians yang homogen. Berdasarkan hasil perhitungan SPSS diperoleh nilai signifikan $=0.30$ sehingga dapat disimpulkan $\mathrm{H} 0$ ditolak dan $\mathrm{H} 1$ diterima karena nilai sig $<\alpha(0.030<0.05)$. jadi dapat disimpulkan terdapat perbedaan yang signifikan antara kemampuan pemahaman konsep matematis siswa yang dibelajarkan menggunakan model pembelajaran Inquiry Learning dengan siswa yang dibelajarkan dengan menggunakan modek pembelajaran Problem Based Learning (PBL).

Hasil penelitian menunjukkan terdapat perbedaan kemampuan pemahaman konsep matematis siswa yang memperoleh pembelajaran dengan model pembelajaran Inquiry Learning dan model pembelajaran Problem Based Learning. Setelah dilakukan pengujian hipotesis dengan menggunakan uji-t (Independent Sample test) berdasarkan hasil perhitungan SPSS diperoleh nilai sig = 0.30 sehingga dapat disimpulkan $\mathrm{H} 0$ ditolak dan $\mathrm{H} 1$ di terima karena nilai $\operatorname{sig}<\alpha$ $(0.03<0.05)$. jadi dapat disimpulkan terdapat perbedaan yang signifikan antara kemampuan pemahaman konsep matematis siswa yang diajarkan dengan model pembelajaran Inquiry Learning dengan siswa yang diajarkan dengan model pembelajaran Problem Based Learning (PBL).

Dari hasil pengujian hipotesis bahwa rata-rata kemampuan pemahaman konsep matematis siswa yang di ajarkan dengan menggunakan model pembelajaran Inquiry Learning lebih tinggi daripada rata-rata kemampuan pemahaman konsep matematis siswa yang diajarkan dengan model pembelajaran Problem Based Learning. hal 


\section{$\pi$ (Phi)}

ini menunjukkan bahwa kemampuan pemahaman matematis melalui model pembelajaran Inquiry Learning lebih baik daripada kemampuan pemahaman konsep matematis melalui model pembelajaran Problem Based Learning pada siswa kelas VII SMPN 05 Kota Jambi.

Pembelajaran Inquiry Learning dipandang lebih efektif karena akan memberikan peluang kepada siswa untuk lebih aktif berdiskusi kelompok dalam proses pembelajarannya. Dalam pembelajaran Inquiry Learning siswa ditekankan dalam pemahaman konsep dan menemukan sendiri konsepnya. Hal ini sesuai dengan pendapat Kunandar (2010:371) menyatakan bahwa pembelajaran Inquiry adalah kegiatan pembelajaran dimana siswa didorong untuk belajar melalui keterlibatan mereka secara aktif dengan konsep-konsep dan prinsip-prinsip Dan guru mendorong siswa untuk memilki pengalaman dan melakukan percobaan yang memungkinkan siswa menemukan prinsipprinsip untuk mereka sendiri. Hal ini juga sejalan dengan penelitian Jamrotul Fitri yang menyatakan bahwa model pembelajaran Inquiry Learning lebih baik karena Inquiry selain menekankan pada menemukan sesuatu siswa juga dapat memahami penyebab dan dampak yang terjadi dalam permasalahan.

\section{SIMPULAN DAN SARAN}

Dari hasil penelitian dan pembahasan yang telah di lakukan dapat disimpulkan bahwa rata-rata kemampuan pemahaman konsep matematis siswa yang mendapatkan pembelajaran dengan model pembelajaran Inquiry Learning pada kelas VII $F$ (eksperimen) diperoleh nilai rata-rata sebesar 82.5dan rata-rata kemampuan pemahaman konsep matematis siswa yang mendapatkan pembelajaran dengan model pembelajaran Problem Based Learning (PBL) pada kelas VII I (kontrol) diperoleh nilai rata-rata sebesar 78.61 .
Terdapat perbedaan kemampuan pemahaman konsep matematis siswa yang pembelajarannya menggunakan model pembelajaran Inquiry Learning dengan model pembelajaran Problem Based Learning (PBL). Hal ini dilihat dari uji hipotesis dengan menggunakan uji-t Independent Sample Test menggunakan Software SPSS versi 20 dengan taraf signifikan 5\%, ternyata diperoleh nilai signifikan $<\alpha(0.03<0.05)$ maka dalam hal ini H0 ditolak dan $\mathrm{H} 1$ diterima. Artinya terdapat perbedaan kemampuan pemahaman konsep matematis siswa antara yang menerapkan model pembelajaran Inquiry Learning dengan yang menerapkan model pembelajaran Problem Based Learning. Berdasarkan analisis data yang telah dikemukakan maka dapat ditarik kesimpulan dari penelitian ini yaitu kemampuan pemahaman konsep matematis siswa yang menerapkan model pembelajaran Inquiry Learning lebih baik daripada kemampuan pemahaman konsep matematis siswa yang menerapkan model pembelajaran Problem Based Learning (PBL) pada siswa kelas VII SMPN 5 Kota Jambi.

\section{DAFTAR PUSTAKA}

Arikunto, Suharsimi. 2013. Prosedur Penelitian Suatu Pendekatan praktik. Jakarta: Rineka Cipta

Fitriani, S. (2015). Perbandingan Hasil Belajar Matematika Siswa Dengan Menerapkan Strategi Pembelajaran Aktif Tipe Practice-Rehearsal Pairs dan Action Learning di Kelas VIII SMP Negeri 16 Kota Jambi: Ekotrans.15 (1), 91-102.

Huda, Miftahul. 2014. Model-Model Pengajaran dan Pembelajaran. Yogyakarta: Pustaka Pelajar

Lestari, E.K, 2015. Penelitian Pendidikan matematika. Bandung: PT Refika Aditama

Riduwan. 2014. Pengantar Statistika. Bandung: Alfabeta 


\section{$\pi$ (Phi)}

Dimyati dan Mudjiono. 2009. Belajar Dan Pembelajaran. Jakarta: Rineka Cipta.

Hamalik, Oemar. 2011. Proses Belajar Mengajar. Jakarta: PT. Bumi Aksara. 